\title{
Nutritional care and candidates for small bowel transplantation
}

\author{
S V Beath, I W Booth, M S Murphy, J A C Buckels, A D Mayer, P J McKiernan, \\ D A Kelly
}

\begin{abstract}
Twenty two children were evaluated for small bowel transplantation between 1989 and 1994. Eight were unfit for transplantation and died within three months; a raised plasma bilirubin concentration $(>200 \mu \mathrm{mol} / \mathrm{/})$ predicted death from liver failure within six months $(p=0 \cdot 0001)$. The 11 children who were not managed by a multidisciplinary nutritional care team were less well nourished at referral, had more complications with intravenous feeding catheters, and greater early mortality while awaiting transplantation $(p<0 \cdot 05)$. It is recommended that children with chronic intestinal failure be referred for assessment early, before liver dysfunction is established.

(Arch Dis Child 1995; 73: 348-350)
\end{abstract}

Keywords: parenteral nutrition, small bowel transplantation, nutritional care.

Parenteral nutrition permits children with chronic intestinal failure, who would otherwise have died in infancy, to survive for many years. It is associated with a number of life threatening complications such as line sepsis, hepatic dysfunction, loss of venous access, ${ }^{12}$ and pulmonary embolism. ${ }^{3}$ Even children on long term parenteral nutrition managed at home experience a range of psychosocial and physical problems requiring constant vigilance and support. ${ }^{4}$

Intestinal transplantation is a logical extension of treatment for patients with complications related to parenteral nutrition, but transplant programs have been restricted by the uniquely intense rejection that occurs in the small bowel. ${ }^{5}$ Isolated intestinal transplants and combined liver and bowel transplants have been undertaken since the $1960 \mathrm{~s},{ }^{6-8}$ but results did not improve until tacrolimus (FK506) became available. Tacrolimus is a similar but more potent immunosuppressant than cyclosporin and has been associated with results improving to $65 \%$ overall survival in 32 paediatric recipients over four years in Pittsburgh ${ }^{9}$ with approximately $50 \%$ survival in 100 operations reported world wide. ${ }^{10}$ The choice of isolated intestinal transplantation or combined with liver, depends on the extent of hepatic damage at the time of transplantation. The observation that concomitantly transplanted liver enhances tolerance to kidney and other organ allografts from the same donor, ${ }^{11}$ and that many patients are referred late, has caused combined small bowel and liver transplantation to be adopted as the operation of choice in developing transplant programs. However, initial results of isolated intestinal transplantation (70-90\% one year survival) compare favourably with the combined operation. ${ }^{912} 13$ The role of the liver in enhancing survival of other grafts may be offset in the case of small bowel transplantation by the effect of escalating hepatic dysfunction in patients who are referred late.

These initial results have stimulated considerable interest and increased referrals of children on long term parenteral nutrition for assessment for isolated or combined transplantation. As many children on long term parenteral nutrition have a satisfactory quality of life, ${ }^{14}$ it is important to establish the appropriate point at which patients should be referred for assessment. Late referral may have serious consequences because patients often experience a long delay before suitable donor organs become available. ${ }^{15} \mathrm{We}$ have evaluated our experience of 22 patients referred for small bowel and/or liver transplantation.

\section{Patients and methods}

Between September 1989 and September 1994, 22 children (age range 4 months- 13 years) with chronic intestinal failure secondary to short gut $(n=12)$, pseudo-obstruction $(n=7)$, and enteropathy $(n=3)$ were evaluated for small bowel transplantation. Nutritional status was assessed by measuring weight, height, mid-arm circumference, and triceps skinfold thickness. The duration of parenteral nutrition, number of feeding catheters, frequency of line sepsis, patency of central veins, hepatic function, and histology at the time of referral were recorded.

\section{Results}

The duration of parenteral nutrition ranged from four months to six years. Twelve children had overt liver disease (bilirubin 120-760 $\mu \mathrm{mol} / \mathrm{l})$ and 10 had severe problems with venous access. All had splenomegaly, eight children had oesophageal varices and ascites, and 17 had abnormal histology on liver biopsy (13 cirrhosis, four fibrosis). All the children were followed up for three to 14 months. Twelve died without undergoing transplantation: eight were too ill to place on the transplant list and four died while awaiting a donor. Except for two children (one died of multiple pulmonary emboli, the other died of sepsis), all the deaths were secondary to liver failure. Two children have undergone combined small bowel and liver transplantation. One died from 


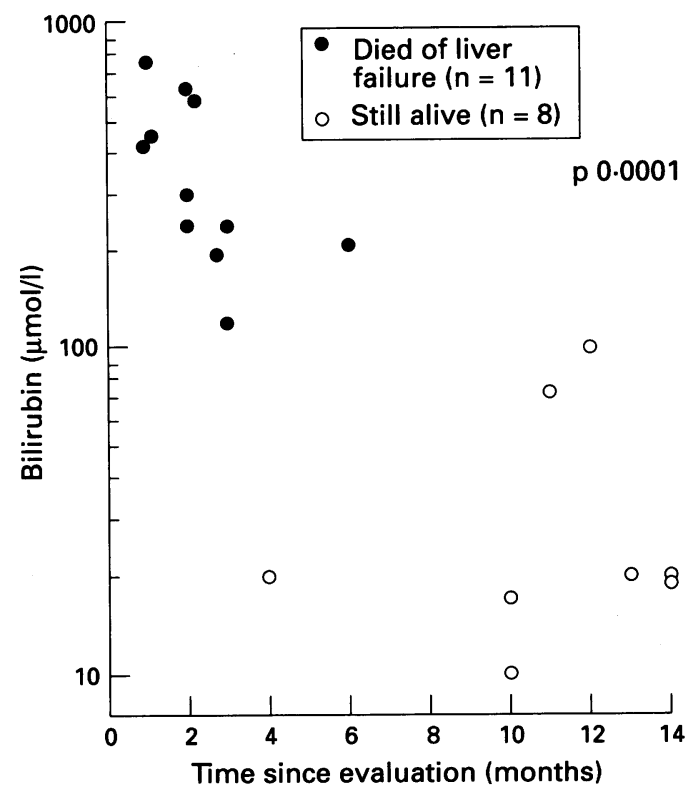

Relationship between plasma bilirubin concentration at evaluation for small bowel and liver transplantation and duration of survival before death from liver failure $(n=19)$; three subjects who died of infection not included. There was a tenfold relative risk of dying if bilirubin concentration was $>200 \mu \mathrm{mol} / \mathrm{by}$ Fisher's exact test.

infection six months after the procedure and one died from pulmonary haemorrhage after six weeks. Seven children remain under observation and are not considered to require transplantation at present. One child is awaiting transplantation.

In those children who died of liver failure, plasma bilirubin concentration at the time of evaluation was related to duration of survival (figure). The relative risk of dying of liver failure within six months was tenfold higher in children with a plasma bilirubin greater than $200 \mu \mathrm{mol} / 1$ at the time of assessment compared with those below $200 \mu \mathrm{mol} / 1 \quad(p=0.0001$, Fisher's exact test). We noted a marked discrepancy in clinical status between children referred for evaluation from centres with and without nutritional care teams and therefore compared these two groups in more detail.

Eleven children had been managed in a centre with an established nutritional care team comprising a nurse specialist, a dietitian, a pharmacist, a social worker, and a clinician. At referral, nutritional status was better $(p=0.05)$ and venous catheter survival longer $(p=0.03)$ in those children managed in centres with a nutritional care team compared with those without (see table). Short term mortality (death within three months of evaluation) was

Clinical features at the time of referral and outcome in children managed in centres with and without nutritional care teams; values are median (range) except where otherwise stated

\begin{tabular}{|c|c|c|c|}
\hline & $\begin{array}{l}\text { Centre with } \\
\text { nutritional care } \\
(n=11)\end{array}$ & $\begin{array}{l}\text { No nutritional } \\
\text { care } \\
(n=11)\end{array}$ & $\stackrel{p}{\text { Value }}$ \\
\hline $\begin{array}{l}\text { Weight z score } \\
\text { Height z score } \\
\text { Interval between line changes (months) } \\
\text { Age (months) } \\
\text { Bilirubin }(\mu \mathrm{mol} / /)\end{array}$ & $\begin{array}{l}-0 \cdot 5(-2 \cdot 1 \text { to } 0 \cdot 82) \\
-1 \cdot 7(-3 \cdot 1 \text { to }-0 \cdot 3) \\
5 \cdot 5(0 \cdot 8-12) \\
29(4-159) \\
20(12-581)\end{array}$ & $\begin{array}{l}-1 \cdot 8(-5 \cdot 8 \text { to } 0 \cdot 39) \\
-2 \cdot 6(-5 \cdot 7 \text { to }-0 \cdot 2) \\
2 \cdot 1(1 \cdot 3-3) \\
11(6-34) \\
240(10-760)\end{array}$ & $\begin{array}{l}0 \cdot 05 \\
0 \cdot 2 \\
0 \cdot 03 \\
0 \cdot 2 \\
0 \cdot 3\end{array}$ \\
\hline $\begin{array}{l}\text { No }(\%) \text { of patients dying within three } \\
\text { months }\end{array}$ & $1(17)$ & $7(87 \cdot 5)$ & 0.03 \\
\hline
\end{tabular}

^By Mann-Whitney except for number of patients dying within three months (Fisher's exact test). much higher $(p=0.03)$ in the children referred from centres without a nutritional care team.

\section{Discussion}

These data suggest that the development of liver disease adversely affects survival in this group of patients particularly in the context of the shortage of donors suitable for young children. ${ }^{915}$ The children from centres with multidisciplinary care teams were significantly better nourished and had experienced fewer central venous line changes than the children managed in centres without a nutritional care team. These observations are consistent with previous findings from this centre supporting the value of a multidisciplinary approach to the management of these children. ${ }^{16} 17$

The occurrence of parenteral nutrition related liver disease is more common in children, especially premature neonates requiring emergency abdominal surgery. ${ }^{12}$ This may be related to the relatively high nutritional requirements for parenteral nutrition infusions in infancy, hepatic immaturity in disposing of potentially toxic substances, for example manganese, and recurrent sepsis either from the intravenous feeding catheter or from bacterial overgrowth in the bowel. ${ }^{18} 19$ Avoidance of complications depends on a multidisciplinary team that can minimise line blockages and infections, ${ }^{16}$ monitor the composition of parenteral nutrition solutions and plasma biochemistry including trace elements and liver function tests. ${ }^{17}$ Nutritional care teams can ensure that residual gut function is maximally utilised with special feeds, tube feeding, and treatments such as antibiotics for bacterial overgrowth and motility agents (for example cisapride, ${ }^{20}$ erythromycin, ${ }^{21}$ loperamide).

Despite optimal management, some children develop liver disease and will need combined small bowel and liver transplantation. Potential candidates for small bowel transplantation should be referred for assessment early, either when splenomegaly develops or when the conjugated bilirubin concentration goes above $100 \mu \mathrm{mol} / 1$. As experience with intestinal transplantation grows, it may be possible to offer transplantation to patients who are stable on home parenteral nutrition before hepatic dysfunction develops. Currently, limited organ availability and postoperative problems with immunosuppression ${ }^{91022} 23$ dictate that small bowel transplantation is reserved for those who are likely to die from complications of parenteral nutrition within one year.

Thus, nutritional care teams provide an essential service for children with intestinal failure who are awaiting small bowel transplantation because they contribute to their longer survival and greater size, which gives them an advantage in the search for suitable donor organs.

The assessment and management of these children was facilitated by members of the dietetic and pharmacy departments, and nursing colleagues in particular Chris Holden, Patrick Ball, and Gill Brook. The skilful replacement of feeding catheters was undertaken by colleagues in the departments of surgery and cardiology at The Childrens' Hospital. 
1 Sax HC, Bower RH. Hepatic complications of total parenteral nutrition. Fournal of Parenteral and Enteral Nutrition 1988; 12: 615-8.

2 Puntis JWL, Ball PA, Booth IW. Complications of neonatal parenteral nutrition. Intensive Therapy and Clinical Monitoring 1987; 8: 48-56.

3 Dollery CM, Sullivan ID, Bauraind O, Bull C, Milla PJ Thrombosis and embolism in long term central venous access for parenteral nutrition. Lancet 1994; 344: 1043-5.

4 Bisset WM, Stepleford P, Long S, Chamberlain A, Sokel B Milla PJ. Home parenteral nutrition in chronic intestina failure. Arch Dis Child 1992; 67: 109-14.

5 Wood RFM, Ingham Clark CL. Small bowel transplantation. $B M \mathcal{F}$ 1992; 304: 1453-4.

6 Lillehei RC, Idezuki Y, Feemster JA, et al. Transplantation of stomach, intestine and pancreas: experimental and clinical observations. Surgery 1967; 62: 721-41.

7 Goulet OJ, Revillon Y, Brousse N, et al. Successful smal bowel transplantation in an infant. Transplantation 1992, 53: $940-3$.

8 Grant D, Wall W, Mimeault R, et al. Successful smallbowel/liver transplantation. Lancet 1990; 335: 181-4.

9 Kocoshis SA. Small bowel transplantation in infants and children. Gastroenterol Clin North Am 1994; 23: and 7272 .

10 Kelly DA, Buckels JAC. The future of small bowel transplantation. Arch Dis Child 1995; 72: 447-51.

11 Calne RY, Sells RA, Pena JR, et al. Induction of immunological tolerance by porcine liver transplantation. Nature 1969; 223: 472-6.

12 Antonson DL, Langnas AN, Mack DR, et al. Combined liver/small intestinal and isolated intestinal transplantation in children. $\mathcal{F}$ Pediatr Gastroenterol Nutr 1994; 19: 330 .
13 Todo S, Murase N, Tzakis A, Starzl TE. Role of liver and the portal circulation in intestinal grafting. In: Grant DR, Wood RFM, eds. Small bowel transplantation. London: Edward Arnold, 1994: 101-11.

14 Amarnath RP, Fleming CR, Perrault J. Home parenteral nutrition in chronic intestinal disease: its effect on growth and development. $\mathcal{F}$ Pediatr Gastroenterol Nutr 1987; 6: and dever.

15 Stein A, Hope T, Baum JD. Organ transplantation:

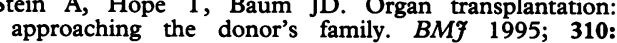
1149-50.

16 Puntis JWL, Holden CE, Smallman S, Finkel Y, George R, Booth IW. Staff training; a key factor in reducing intravascular catheter sepsis. Arch Dis Child 1991; 66: 335-7.

17 Smallman S, Handy D, Puntis JWL, Booth IW. The nutrition team in a children's hospital. Nutr Health 1987; 5: 137-44.

18 Reynolds AP, Kiely E, Meadows N. Manganese in long term paediatric parenteral nutrition. Arch Dis Child 1994; 71: 527-8.

19 Capron JP, Gineston J, Herve MA, Braillon A Metronidazole in prevention of cholestasis associated with total parenteral nutrition. Lancet 1983; i: 446-7.

20 Puntis JWL, Buick RU, Booth IW. Cisapride in neonatal short gut syndrome. Lancet 1986; i: 108-9.

21 Simpkiss D, Adams I, Myrdal U, Booth IW. Erythromycin in severe post-operative intestinal dysmotility in the in severe post-operative intestinal dysm
neonate. Arch Dis Child 1994; 71: F128-9.

22 Tzakis A, Todo S, Reyes J, et al. Clinical intestinal transplantation: focus on complications. Transplant Proc 1992; 24: $1238-40$.

23 Beath SV, Kelly DA, Booth IW, Freeman J, Buckels JAC, Mayer AD. Postoperative care of children undergoing fournal of Intensive Care 1994; 4: 302-8. 